\title{
The Supply of Small Arms and Light Weapons to Conflict Zones: The Bane of Onset, Intensity and Duration of Armed Conflict in Africa
}

\author{
Osimen, Goddy Uwa ${ }^{1} \quad$ Rufus Aisedion, $P h . D^{2} \quad$ Isaac Adi, Ph.D ${ }^{3}$ \\ 1.Department of Political Science \& International Relations Achievers University, Owo \\ 2.Department of Political Science, Ambrose Alli University, Ekpoma, Edo State \\ 3.Department of Criminology, Security \& Peace Studies, Caleb University, Lagos
}

\begin{abstract}
Small arms fuel violence and intensify human suffering in conflict situations across the globe. The illicit trafficking, proliferation and misuse of small arms have grave impacts on human security, development and human rights. They hamper conflict resolution, peace-building and commercial activities in various parts of the world, affecting the lives of millions. In recent years, attention has come to focus on the ways in which the increased availability of low-cost small arms and light weapons contributes to the likelihood, intensity and duration of armed conflict. This paper has examined the full range of sources of small arms in Africa region. It recognizes the importance of large international transfers in weapons sourcing to conflict zones; at the same time, however, it reinforces lesser-known findings regarding the role of production, government stockpiles, and the socalled ant trade in the fuelling conflict. For more emphasis, the paper is anchored on the combination of three different theories; the theory of relative autonomy of state, conflict theory and failed state theory. In developing a more comprehensive approach to conflict sourcing, the role of politics must not be overlooked. Small arms proliferation is essentially a political issue, as the politically motivated leakages from military stockpiles and state-sponsored transfers in the region. The paper further reveled that government stockpiles is an important source of weapons in many conflict zones, through corruption, theft, seizure, distribution, and sales. In some conflicts, they are even the main source of small arms for all combatants. As observed, in the long run, persistent smaller shipments of small arms can be more significant in terms of volume than occasional large-scale trafficking of guns. Where the ant trade is important, policy responses become more complicated. Therefore, to control brokering, streamlining end-user certificates, and establishing arms embargoes, an effective policy also needs to tackle corruption and make the control of border regions and of the border itself more effective. In addition, policies must be tailored to individual states. While regional and international approaches are useful, their limitations must also be clearly understood.
\end{abstract}

Keywords: Small Arms, Light Weapons, Proliferation, Arms supply, Armed Conflict, Africa

DOI: $10.7176 / \mathrm{IAGS} / 88-01$

Publication date: November $30^{\text {th }} 2020$

\section{Introduction}

“.....illicit arms transfers to conflict and war zones often display features characteristic of newsworthy stories. They tend to involve shady, greedy dealers and financiers with Hollywood-type lifestyles; suspicious means of transport, with airplane registrations being changed mid-flight and jets sometimes touching down on tarmac in the middle of the jungle; and disturbingly ruthless recipients. Some cases embroil politicians and other public figures. No wonder, then, that the media are particularly eager to cover this aspect of the small arms problem". Anna Khakee \& Nicolas Florquin, (2005).

During an armed conflict, there is a continual circulation of arms between factions, as weapons are captured and stolen by all sides. Such sources of arms remain significant, even for insurgent groups that have secured access to an external supply of arms in the early stages of the conflict. For example, the National Patriotic Front of Liberia and the Revolutionary United Front (RUF) of Sierra Leone had all secured supply lines either prior to the outbreak of violence or early in the conflict, but nonetheless continued to obtain stocks within the conflict complex, through theft and capture. Some of the weapons in armed groups' stockpiles are acquired during attacks on police and military armories (Jeffrey and Michael, 1998). Leakages from poorly constructed and insecure stockpiles are also a chronic problem in African countries with large numbers of weapons, both during and before and after conflict. Under resourced security forces may be unable to secure stockpiles properly, and poorly paid individuals may resort to using their official weapons for criminal activities or may rent them out to others to supplement their income. Small arms and light weapons (SALW) enable and facilitate armed conflict, terrorism, and crime (Small Arms Survey, 2016). Today, they remain among the cheapest and most easily accessible instruments for participating in violence. Despite our understanding of the threat posed by SALW to peace and security, development and human rights, deep-rooted differences remain on how to stem their ill effects, in particular the passage of weapons from the licit realm to the illicit. Even the domestic passage of 
SALW to the illicit realm can, ultimately, have transnational effects, fueling conflict, crime, and terrorism.

The extent to which illicit trade in small arms is a primary cause of armed conflict and other serious humanitarian and socioeconomic issues has drawn controversy. The extremely high instance of small arms violence and the presence of illicitly obtained weapons, especially in areas of turmoil and armed conflict, are undisputed. Because other societal factors play a strong role in creating armed conflict, however, the role of such weapons as a driver of continued violence and disruption has been called into question. Recent scholarship has focused on the root societal causes for violence in addition to the enabling tools. Another target of criticism is the ability to regulate illicit trafficking through international means, since it is unclear exactly what proportion of the weapons are trafficked across borders. The nature of the trafficking enterprise makes exact statistics difficult to determine. Recently, however, researchers have had some success establishing hard numbers within limited parameters (Small Arms Survey, 2013).

The persistence and the complication of wars in Africa are partially due to small arms proliferation. The consequences of small arms on African people due to international conflicts within Africa, rebel group activities, mercenary groups, and armed gang activities have yet to be fully measured ( Bahati, 2009). The International Action Network on Small Arms, Safer world, and Oxfam International put it in perspective when they reported that armed conflict cost Africa $\$ 18$ billion each year and about US\$300 billion between 1999-2010. During this period, 23 African nations experienced war: Algeria, Angola, Burundi, Central Africa Republic, Chad, Democratic Republic of Congo (DRC), Republic of Congo, Côte d'Ivoire, Djibouti, Eritrea, Ethiopia, Ghana, Guinea, Guinea-Bissau, Liberia, Niger, Nigeria, Rwanda, Senegal, Sierra Leone, South Africa, Sudan, and Uganda(IANSA,2007).

One of defining characteristics of such conflict is the fact that widespread death and suffering result not from the major conventional weapons traditionally associated with war tanks, aircraft and warships, are all but from small arms and light weapons. The global proliferation of assault rifles, machine guns, mortars, rocketpropelled grenades and other "man-portable" weapons has increased both the frequency and intensity of modern conflict and greatly complicated the task of restoring peace. Such weapons are readily obtainable on international markets, both legal and illicit, and are easily mastered by untrained and unprofessional soldiers, even children. Of the 49 major conflicts that have broken out since 1990, light weapons were the only arms used in 46; only one conflict (the 1991 Gulf War) was dominated by heavy weapons (Jeffrey, and Michael, 1998). Since 1990, these conflicts have resulted in the deaths of more than 4 million people and have produced 20 million refugees and 24 million displaced persons. (Steven, 1996) The resources of the international community are being overwhelmed by bitter conflicts, large-scale refugee movements and even genocide. In response to these disasters, the international community has spent tens of billions of dollars on emergency relief, refugee care and resettlement, peacekeeping, and direct military intervention. For the United Nations alone, the annual cost of humanitarian assistance and relief for war victims has increased ten-fold, from about $\$ 300$ million a year in the 1980 s to $\$ 3$ billion a year in the mid-1990s.

Clearly, the unchecked flow of small arms and light weapons to areas of conflict represents a significant threat to world peace and security. While it cannot be said that such weapons are a primary cause of conflict, their worldwide availability, low cost and ease of operation make it relatively easy for potential belligerents of all kinds to initiate and sustain deadly conflict. Accordingly, policy-makers have begun to highlight the need for new international controls in this area. In a January 2010 message to the UN Conference on Disarmament, Secretary-General Kofi Annan said, "With regard to conventional weapons, there is a growing awareness among member-states of the urgent need to adopt measures to reduce the transfer of small arms and light weapons. It is now incumbent on all of us to translate this shared awareness into decisive action. (Kofi, 2010). Interest in the trade in light weapons has also been spurred by a growing number of national and international nongovernmental organizations (NGOs), many of which played a key role in the international campaign to ban landmines. Along with UN officials and leaders of interested governments, these groups have led the search for new policy prescriptions.

Operationally, the United Nations has sought to monitor the effectiveness of various international embargoes on the transfer of weaponry into areas of conflict. In 1996, a UN International Commission of Inquiry on Rwanda investigated the implementation of the UN arms embargo on Rwanda, paying particular attention to specific allegations of embargo violations. Other international organizations are also becoming involved in the light weapons issue, particularly as it relates to issues of economic and human development. The World Bank is devoting resources to issues of post-conflict reconstruction, particularly in regard to the demobilization of combatants and their reintegration into civil society. Also, the Organization for Economic Cooperation and Development (OECD), through its task force on Conflict, Peace and Development Cooperation, is putting greater emphasis on the need for "timely prevention measures" (such as limiting arms flows in areas of potential conflict) in order to forestall armed violence. Particularly in Africa and the Americas, national governments and regional organizations are devising a variety of measures to better regulate the legal trade in light weapons and to combat illicit weapons trafficking. In November 1997, the Organization of American States (OAS) signed a 
convention on the illicit weapons trade that calls for standardization of national firearms regulations and increased law enforcement and customs cooperation to prevent illicit weapons flows within the Western Hemisphere. The OAS has also developed model regulations that focus on the linkages between the narcotics trade and weapons smuggling. Within the Caribbean sub-region, moreover, Jamaica has proposed that similar efforts be undertaken by the 14-member Caribbean Community (Small Arms Survey, 2016).

In recent years, attention has come to focus on the ways in which the increased availability of low-cost small arms and light weapons contributes to the likelihood, intensity and duration of armed conflict. Although these conflicts often possess deep and complex roots, it is evident that the widespread availability of modern light weapons has emboldened belligerents to pursue their objectives on the battlefield, rather than at the bargaining table. An analysis of this contemporary warfare also reveals that such conflict overwhelmingly takes place in the world's poorest countries. In the 1990s, 30 of the 60 least-developed countries in the world have experienced conflict directly, while another 12 have had to support large refugee populations from neighboring countries in conflict (Steven, 1996). This correlation between conflict and poverty helps explain why these conflicts are generally fought with relatively inexpensive small arms and light weapons. It also explains why the victims of these conflicts are so dependent on assistance from the international community. According to Africa Council for Religions Leaders (2006), Small arms are relatively low tech tools of war, and due to state-driven demand, there are well over 600 suppliers around the world. With more than 550 million in circulation whether newly produced, liquidated by downsizing militaries or circulated from conflict to conflict and small arms are inexpensive and easily diffused. The increasing availability of rapid-fire military assault rifles, automatic pistols and submachine guns and their distribution to non-state actors have given such actors a firepower that often exceeds that of police or military forces. The adoption of newly available technology into shoulder-fired rockets, mortars and light antitank weapons has magnified the presence of warring factions in civil conflicts.

\section{Conceptualization of Terms}

Small arms proliferation is a related term used to describe the growth in both the authorized and the illicit markets. Users of the term have notably included Kofi Annan an ex-Secretary-General of the UN. The small arms market includes legal and illegal transfers. Legal transfers are generally defined as those approved by the involved governments and in accord with national and international law. Black market (illegal) transfers clearly violate either national or international law and take place without official government authorization.

What are small arms and light weapons? There is no universally accepted definition of a 'small arm' or of a 'light weapon'. The Small Arms Survey uses the term 'small arms and light weapons' to cover military-style small arms and light weapons as well as commercial firearms (handguns and long guns).

According to the UN, small arms and light weapons are weapons that can be transported and used by one person or a small crew. Small arms are revolvers and self-loading pistols, rifles and carbines, assault rifles, sub-machine guns, and light machine guns. Light weapons are heavy machine guns, hand-held underbarrel and mounted grenade launchers, portable anti-tank and anti-aircraft guns, recoilless rifles, portable launchers of anti-tank and anti-aircraft missile systems, and mortars with calibers of less than 100 millimeters (UNGA, 2005).

One of the most widely accepted definitions comes from the 1997 report of the United Nations Panel of Governmental Experts on Small Arms. In general terms,

'small arms' are designed for personal use and may be carried by one person; 'light weapons' are used by several persons or a crew and may be transported by two or more people, a pack animal, or a light vehicle (UNGA, 2005a, paras. 25, 27a)) . The International Tracing Instrument provides the following definition of small arms and light weapons:

any man-portable lethal weapon that expels or launches, is designed to expel or launch, or may be readily converted to expel or launch a shot, bullet or projectile by the action of an explosive, excluding antique small arms and light weapons or their replicas (UNGA, 2005b,). It then goes on to note that, broadly speaking, small arms are 'weapons designed for individual use' and light weapons are 'weapons designed for use by two or three persons serving as a crew, although some may be carried and used by a single person' (UNGA, 2005b). It subsequently repeats the list of examples provided in the 1997 UN Panel report.

What are firearms? A legally binding definition of 'firearm' is contained in the Firearms Protocol (see Part 2.1), which provides:

'Firearm' shall mean any portable barreled weapon that expels, is designed to expel or may be readily converted to expel a shot, bullet or projectile by the action of an explosive, excluding antique firearms or their replicas. Antique firearms and their replicas shall be defined in accordance with domestic law. In no case, however, shall antique firearms include firearms manufactured after 1899 (UNGA, 2005c, art. 3(a)).

According to ECOWAS Convention definition: 
'Small arms' refers to arms used by one person, and which include firearms and other destructive arms or devices such as exploding bombs, incendiary bombs or gas bombs, grenades, rocket launchers, missiles, missile systems or landmines; revolvers and pistols with automatic loading; rifles and carbines; machine guns; assault rifles; and light machine guns. 'Light weapons' are portable arms designed to be used by several persons working together in a team, and which include heavy machine guns, portable grenade launchers, mobile or mounted portable anti-aircraft cannons; portable anti-tank cannons, non-recoil guns; portable anti-tank missile launchers or rocket launchers; portable anti-aircraft missile launchers; and mortars with a calibre of less than 100 millimetres.

What is the difference between a small arm and a firearm? The terms 'small arm' and 'firearm' are often used interchangeably. Generally speaking, the term 'firearm' is used in domestic settings and national laws governing the manufacture and transfer of such weapons, as well as civilian access to them; the term 'small arm' is more commonly used to refer to the weapon an individual may use and carry in a military context. In this paper, the terms 'small arm' and 'firearm' are used interchangeably unless the context indicates otherwise. While the definition of 'firearm' adopted by the Firearms Protocol covers all 'small arms, its coverage of 'light weapons' is limited in two ways. First, the weapon must have a barrel since the definition covers 'portable barrelled weapons'. This excludes light weapons that employ a tube or rail as opposed to a barrel, such as manportable air defense systems (MANPADS). Second, the weapon must 'expel' the projectile in contrast to the definition of 'small arms and light weapons' in the International Tracing Instrument, which covers any weapon that 'expels or launches' the projectile. This excludes those light weapons that use self-propelled projectiles, such as rockets or missiles (Berman, 2008). In these cases, the weapon does not 'expel' (drive out) the projectile as required by the definition. In essence, only light weapons that use cartridge-based ammunition qualify as 'firearms' under the Firearms Protocol definition (McDonald, 2005).

The UN program does not define small arms or light weapons, but they are usually understood as:

"a subcategory of conventional arms that includes firearms and other small arms, such as pistols, revolvers, and assault rifles, as well as light weapons such as heavy machine guns, man-portable air defense systems, and howitzers with calibers of less than 100 millimeters." UNIDR, (2006)

Secondly, let us also, examine the concept of armed conflict, in particular as regards its meaning and its content:

In its general usage the term "conflict" suggests difference and disagreement, strife and struggle. As defined by Hocker Wilmot (1995), conflict is the interaction of independent people who perceive incompatible goals and interference from each other in achieving goals.

\section{Theoretical Issues}

This study is anchored on the combination of three different theories; the theory of relative autonomy of state, conflict theory and failed state theory (Osimen and Akintunde, 2015). The state relative autonomy theory is situated within the ambit of the neo-Marxist political economy paradigm. The theory of relative state autonomy depicts the level or degree of detachment or aloofness of the state in the discharge of its duties such as mediating inter-class and intra-class struggles. Thus, this theory presupposes that in any state or political society, there are two levels of contradiction, namely primary contradiction and secondary contradiction. Primary contradiction is inter-class struggle or depicts class struggle between two antagonistic classes such as the ruling class and the ruled class or the bourgeois class and the proletariat (i.e. the working class). Whilst, secondary contradiction is the intra-class struggle, denoting class conflicts within the ruling-class or between different segments of the ruling-class. Marx and Engels demonstrate this intractable phenomenon of class struggle when they declare in the preface of their book, The Communist Manifesto that "the history of all the hitherto existing society is the history of class struggles" (Marx and Engels, 1977). The exponents of the theory hold that a state can exhibit either low or high relative autonomy. A state exhibits high autonomy when there is high commodification of capital or excessive penetration of capital into the economy such that the bourgeois class indulges in accumulation of capital through direct exploitation of the working class or appropriation of surplus value when they enter into social relationships of production (i.e. private capitalism). Here, the state is not interventionist, in other words, it does not intervene in the domestic economy like participating in the productive activities (i.e. public/state enterprises) or controlling or nationalizing means of production. The role of state here, therefore, is to regulate. As such, the state is relatively an impartial umpire meditating inter-class and intra-class struggles through harmonization and reconciliation of class interests. Conversely, a state exhibits low autonomy when there is low commodification of capital or low penetration of (private) capital into the economy in such a way that the ruling class is constantly engage in primitive accumulation of capital through embezzlement of public fund. The state becomes the only avenue for capital accumulation. (Osimen and Akintunde, 2015). The state is thus, interventionist for engaging in productive activities of means of productive activities (i.e. public corporation) by nationalization of major means of production. This state does not limit itself to regulatory rule and is hence compromised, such that instead of rising above class struggle it is deeply immersed in it (Ake, 
2001). The Africa states like other developing countries exhibits a low level of the autonomy of the state as a result of low commodification of capital. On the other hand, conflict theory has a long history in sociology and without question; Karl Marx's work in the early to mid-1800s formed the initial statements of this perspective. As you know, Marx was centrally concerned with class and the dialectics of capitalism. He argued that capitalism would produce its own gravediggers by creating the conditions under which class consciousness and a failing economy would come into existence. In this juncture between structure and class-based group experience, the working class revolution would take place. In general, conflict theory seeks to scientifically explain the general contours of conflict in society: how conflict starts and varies, and the effects it brings to bear, which has been the major issue in Africa. The central concerns of conflict theory are the unequal distribution of scarce resources and power. What these resources are might be different for each theorist, but conflict theorists usually work with Weber's three systems of stratification: class, status, and power. Conflict theorists generally see power as the central feature of society, rather than thinking of society as held together by collective agreement concerning a cohesive set of cultural standards, as functionalists do. Where power is located depends who uses it and who doesn't are thus fundamental to conflict theory. In this way of thinking about things, power is not necessarily bad; it is a primary factor that guides society and social relations. The developed capitalist states of the West are, therefore, considered to exemplify this high relative autonomy, and as a result, exhibit high level of human rights observance and protection Ake, (1985). Hence, most the Africa states becomes the only avenue for (primitive) accumulation of capital through which the governing classes (i.e. petty bourgeoisie) produces and reproduces their dominance. The implication of the low autonomy of the Africans is that it is immersed in the class struggle rather than rising above it leading to intense struggle for the control of the state for primitive accumulation and marginalization of everything (Ake, 2001). According to Anyanwu (2005) the term "failed state" is often used to describe a state perceived as having failed at some of basic conditions and responsibilities of a sovereign government. A failed state is one that has shattered social and political structures. It is characterized by social, political and economic failure. Common characteristics of a failing state is when a central government is so weak or ineffective that it has little practical control over much of its territory, nonprovision of public utilities or services, widespread corruption and criminality; refugees and involuntary movement of populations, and sharp economic decline. Anyanwu (2005) further notes that failing states are invariably the product of a collapse of the power structures providing political supports for law and order, a process generally trigged and accompanied by anarchic forms of internal violence. It is the collapse of state institutions, especially the police and judiciary with resulting paralysis of governance, a breakdown of law and order, and general banditry and chaos. Not only are the functions of government suspended, but its assets are destroyed or looted; and experienced officials are killed or flee the country.

From the socialist states of the former Soviet bloc to Africa and Asia, we have witnessed the outbreak of ethnic, religious, racial, linguistic and other forms of communal strife and the melting away of social norms and government structures that would otherwise contain the violence (Jeffrey, and Michael, 1998). Adding to the disorder, in many instances, has been a significant upsurge in armed banditry and criminal violence in all parts of African states.

The importance of this "failed state syndrome" during this decade according to Jeffrey Boutwell, a director of international security studies at the American Academy of Arts and Sciences in Cambridge, can hardly be overstated. The very nature of conflict has been transformed from traditional combat between nation-states to inter-communal conflict within states. Such strife typically involves a wide variety of actors, including governments, rebel movements, armed political militias, ethnic and religious groups, tribes and clans, expatriate and diaspora groups, criminal gangs and mercenaries. Common distinguishing characteristics of this type of intra-state conflict include multiple warring parties, blurred lines of conflict, greater involvement of civilians, and the fact that the conflict itself is not fought on traditional battlegrounds but in local communities; indeed, within society itself. Also characteristic of these conflicts is the presence among the warring parties of irregular and paramilitary forces with little or no formal military training and little compunction about violating the rules of war. All too often, it is children and teenagers who are recruited or forced into these organizations and then made to kill loot and rampage. During the armed conflict, there is a continual circulation of arms between factions, as weapons are captured and stolen by all sides. Such sources of arms remain significant, even for insurgent groups that have secured access to an external supply of arms in the early stages of the conflict.

\section{Sourcing and Supplies of Small Arms to Armed Conflict Zones in Africa}

How do SALWs circulate and get to the hands of terrorist as the end users in Africa?

The global spread of small arms and light weapons has been facilitated by the emergence in many states, including a dozen or more developing countries, of a domestic capacity for the manufacture of such weapons. Whereas the fabrication of major weapons systems is highly concentrated, with only a dozen or so states capable of producing modern tanks, planes and warships, (Francis, 2009) some 50 nations now manufacture light weapons and/or ammunition of various types. The production of modern assault rifles, for example, occurs in 
many of the industrialized nations as well as in Argentina, Brazil, Chile, Egypt, India, Indonesia, Iran, Iraq, Israel, Mexico, North Korea, Pakistan, Saudi Arabia, Singapore, South Africa, South Korea, Taiwan and Turkey. Many of these countries produce arms for export as well as domestic use, greatly adding to the number of sources from which a potential belligerent can obtain weapons of war. Contributing factors include lax arms export controls in supplier countries, sub-regional allies who provide cover and sometimes financing (for example Burkina Faso facilitated the supply of arms to Liberia, despite a UN embargo) and transnational arms dealers motivated by profit to break the law (Francis, 2009). Another key factor is the ability of embargoed buyers to use misappropriated funds or trade valuable commodities, such as diamonds, crude oil or timber concessions, for arms.

The following list of legal, illegal and covert methods by which small arms and light weapons are sold transferred and exchanged underscores according to Jeffrey Boutwell and Michael Klare, 1998 in a paper titled; Small Arms and Light Weapons: Controlling the Real Instruments of War:

a. Grants or gifts by governments to allied governments abroad;

b. Sales by governments to client governments abroad;

c. Commercial sales by private firms to governments and private dealers in other countries;

d. Technology transfers associated with domestic arms production in the developing nations;

e. Covert transfers by governments to friendly insurgent and separatist groups in other countries;

f. Gifts by governments to armed militias and paramilitary organizations linked to the ruling party or the dominant ethnic group;

g. Black-market sales to the governments of "pariah" countries and to insurgent and separatist forces;

h. Theft of government and privately owned arms by insurgent, criminal and separatist forces; and

i. Exchanges between insurgent and criminal organizations, whether for profit or in pursuit of common political objectives.

Although it is impossible to discuss each of these methods in detail, it is useful to look briefly at the major channels.

i. Legal Channels. Currently, there are over 300 manufacturers of light weapons and related equipment in 50 countries around the world, a 25 percent increase in the last decade alone (Swadesh, 1995). Until the end of World War II, the major producers of these weapons were the industrialized nations. In recent decades, however, these established producers have been joined by China, Israel, South Africa and many developing countries. Estimates of some common models produced by these countries in the past few decades show the enormity of the problem: 5 million to 7 million Belgian FAL assault rifles produced in 15 countries; 35 million to 50 million Soviet/Russian AK assault rifles manufactured by Soviet/Russian factories and licensees; 7 million German Heckler \& Koch G3 assault rifles made in 18 countries; 8 million U.S. M-16 rifles produced in seven countries; and 6 million Chinese-made AK-type assault rifles. (Jeffrey, and Michael, 1995). These numbers, as alarming as they are, do not include the millions of surplus arms that have been sold or given away as the world's major military powers have reduced their forces and/or found themselves with excess production capacity following the end of the Cold War.

ii. Covert and 'Gray-Market' Channels. In addition to legal sales and military assistance programs, small arms and light weapons are disseminated through covert and "gray-market" channels (that is, channels that operate with government support even though in violation of official government policy), most often by government intelligence agencies or private companies linked to such agencies. During the Soviet occupation of Afghanistan, the CIA helped to supply some 3 million AK-47 assault rifles (mainly Chinese and Egyptian models) to rebel mujahideen; thousands of these weapons have since turned up in fighting in Kashmir and elsewhere in South Asia, and as far away as Southeast Asia and the Middle East. In addition, the United States and the Soviet Union supplied arms to rebel groups in Central America and sent massive amounts of weapons to various factions in Angola and Mozambique. Since the end of the Cold War, Washington and Moscow have discontinued many of these activities. But it is widely believed that military commanders and managers of military factories in Russia and some of the other newly independent states of the former Soviet Union have engaged in large-scale covert sales of weapons to clients in neighboring states and beyond (Jeffrey, and Michael, 1995). Government officials in other states have also been accused of smuggling arms to allied groups in other countries, whether for profit or to advance particular political or religious objectives. Officials in Zaire, for instance, reportedly bought large quantities of weapons on the international market and sold them to UNITA forces in Angola for profits running into the hundreds of millions of dollars with most of which is believed to have wound up in the overseas bank accounts of former President Mobutu Seso Seko and his associates. Another form of gray-market transfers entails the delivery of weapons from government stockpiles to political entities and ethnic militias associated with the ruling clan or party. Prior to the 1994 genocide in Rwanda, for example, the Hutu-dominated government distributed small arms and 
machetes to government-linked militias. Once the killing began, the Rwandan military sought to crush any organized Tutsi resistance while the militias slaughtered unarmed Tutsis and moderate Hutus. A similar pattern was evident in Haiti in the early 1990s, when the ruling military junta organized and armed the Front for the Advancement and Progress of Haiti (FRAPH) to suppress popular support for ousted President Jean-Bertrand Aristide.

iii. Illicit and Black-Market Channels. The third major category of light weapons transfers according to according to Jeffrey Boutwell and Michael Klare, includes illegal sales through black-market channels, the supply of arms in defiance of international embargoes and other legal sanctions, and the theft of arms from government stocks or private citizens. In recent years, there has been a striking growth in the operations of black-market dealers to satisfy the needs of non-state actors in ethnic and internal conflicts. Because such actors are normally barred from purchases on the legal munitions market, they must acquire their weaponry from illicit sources. The growing number of UN arms embargoes has also produced an increased demand for black-market arms. Although it is impossible to estimate the value or scale of all such transactions, some estimates place 1993 black market sales to the belligerents in Bosnia alone at $\$ 2$ billion or more (Jeffrey, and Michael, 1995). The smugglers use speed-boats to connect to the high seas, and then ferry the arms back to shore. Looking at the armed conflict in the Niger Delta region of Nigeria, SALW are brought into the delta from various locations. Most of the weapons, such as the Russian AK-47, the German G-3, the Belgian FN-FAL, Czech machine guns and Serbian rocketpropelled grenades (RPGs) are supplied by illegal dealers and sellers, who are paid through the proceeds of bunkered (stolen) oil. In October 2006 the Rivers State Police Commissioner arrested one Chris Ndudi Njoku, a Nigerian businessman who specialized in importing prohibited firearms into Nigeria. In his possession were G-3s, AK-47s and Beretta automatic rifles. European dealers are also involved in the trade with their African counterparts, but rarely have to face justice. The black-market trade has been facilitated by the existence of vast stockpiles of surplus arms in the states of the former Soviet bloc which in many cases are guarded by near-destitute soldiers and officers who are all too eager to conspire in their theft by black-market dealers or to enter the illicit trade themselves. Moreover, there are strong linkages between the illegal narcotics trade and black-market arms trafficking. These underground networks have developed sophisticated methods for the procurement, transportation and sale of small arms and light weapons, at times with the connivance of governments or corrupt public officials.

iv. Arms trafficking and Smuggling: Weapons are circulating at all levels from the smuggling of individual weapons to large shipments. Recent research assessing the border threat, noted the patterns of arrival and circulation of small arms within the Mano River Union (Guinea, Liberia and Sierra Leone). Communities interviewed disclosed that during the civil wars in Liberia and Sierra Leone, illicit trade in small arms and light weapons, particularly AK-47s, RPGs, FM light machine guns, M16 rifles, two-barrel Berettas, pistols, bazookas and mortars, increased along the Koinadugu -Kailahun axis of Sierra Leone. Some of these arms and ammunition are still being trafficked into Sierra Leone from Guinea and Liberia and vice versa. The assessment report identified the Guinea Forest and the Parrot Beak regions as the most prominent routes for trafficking arms within the Mano River Basin. The borders between West Africa's states are long and full of footpaths, which are poorly patrolled. More than 150 illegal crossing points were identified to and from Sierra Leone and Guinea and Liberia. Over $85 \%$ of crossing points were covered by fewer than $11 \%$ of the customs, immigration and security officials identified. The Sierra Leone Border Threat Assessment Report established that smuggling of SALW can be a real threat to stability in the Mano River Basin. In mid-2003, while conflict raged in Liberia, the government of Guinea imported mortar rounds and other ammunition from Iran. These were declared on cargo documents as "detergent" and "technical equipment 10 From Guinea, the weapons were forwarded to allied rebels inside Liberia who had just launched two offences on the capital, Monrovia. The rebels of Liberians United for Reconciliation and Democracy used these weapons to fire indiscriminately on civilian areas of Monrovia. Just as weapons are recycled from conflict to conflict in West Africa, so too are some of the fighters. There is a thriving trade in mercenaries in West Africa, aiding the circulation and proliferation of small arms in the region

v. Finally, theft of weapons from military and police warehouses is a major problem in countries afflicted by civil war or insurgent violence. As civil strife spread across Albania in the spring of 1997, thousands of weapons were looted from military depots by insurgents, criminals and civilians. These weapons not only increased the levels of armed violence in Albania, but reportedly were also being smuggled across the border into the Serbian province of Kosovo, where 2 million ethnic Albanians pose an irredentist challenge to Serbian authority. In South Africa and Colombia, stolen weapons contribute to a culture of violence and criminality that undermines the stability of the state and the cohesion of society. SALW also circulate through the desertion of military personnel. Many of these legal weapons find their way 
into the illicit market. But not all weapons are externally manufactured and sourced: artisan firearms are now being made in such profusion that they constitute a major problem across West Africa. Blacksmiths have a significant role in the manufacture and circulation of firearms in Ghana, and this trend has spread to other countries within the sub region. Made with heavy, cast iron barrels, aluminium firing mechanisms and rough wooden handles, these weapons are the pride and joy of hundreds of blacksmiths and illicit cooperatives of artisans across Ghana. There are an estimated 75,000 illegal craft guns now circulating in Ghana, constituting the vast majority of the 125,000 unregistered weapons in the country. Around $80 \%$ of the weapons seized by the police and the Ghanaian security forces are locally manufactured (Virginia, 1995). According to a governance campaigner for the United Nations Development Programme (UNDP), "Industrial weapons are getting harder and harder to get in Ghana because of the restrictions on the international arms trade and the local guns are filling the gap. They may look heavy and crude but they are no less dangerous" (Francis, 2009). It is estimated that up to one-third of the 400 murders in Ghana every year are committed with a craft gun. At least 400 blacksmiths in southern Ghana are now serving the industry, each capable of making up to 80 guns per year. The picture is similar in other parts of West Africa: craft guns were widely used in the civil wars that killed hundreds of thousands in Sierra Leone and Liberia, and countries including Mali have been pinpointed as major manufacturing centers. "When the war ends, the guns remain", is a common refrain among West Africans. After conflict, small arms are recycled for use in new conflicts and crime at home, or sold to other West African countries for use in new conflicts or to prolong ongoing conflicts. The easy availability of small arms and their circulation within and across borders facilitates the formation of new armed groups and new conflicts; it also facilitates the use of untrained civilian militias, ill-disciplined fighters, and unaccountable mercenaries. According to Africa Council for Religions Leaders (2006), about $40 \%$ of SALW are estimated to be in civilian hands, and most countries in West Africa have outdated arms control ordinances and legislation, which date back to the colonial era.

\section{Effects of Small Arms and Light Weapons Proliferation in Africa}

Proliferation of small arms and light weapons (SALW) has had, and will continue to have devastating consequences in Africa Regions except with good measures. The numbers of state-based conflicts have increased in Africa over the past 20 years. In 2017 Africa experienced 18 state-based conflicts while, this was a decrease from the all-time high of 21 in 2016, it is substantially higher than 2010, with 12 conflicts in 2007. Continued conflicts throughout the region over the past decades have contributed to the ever increasing requirement for the small arms and light weapons as the primary tools of violence, causing deaths and injuring thousands of people, among them innocent civilians (Frankonero, 2008). The wake of insecurity in the region continues to threaten democracy and stability thereby impacting negatively on trade and economic growth. In spite of the endowment with many natural resources, the region has some of the poorest nations of the world. Poor governance and insecurity, coupled with corruption, has also contributed to inability of the countries concerned to deter the trading and spread of weapons in the region. Premised on this reality, most countries, however, have acknowledged the need for initiatives and policies to arrest the problem of Proliferation of SALW and its negative drawback on the economic development in the Sub-Saharan Africa. But even with efforts through regional trading blocs and initiatives of the international community, success is yet to be realized due to lack of government control in the region to deter the trading and spread of weapons on the continent, where machine guns, rifles, grenades, pistols and other small arms have killed and displaced many civilians across the continent. These weapons have been used in deadly conflicts in Sudan, Uganda, Sierra Leone, Rwanda, Angola, the Democratic Republic of Congo, Somalia and other African countries.

The direct human costs of a conflict are seen in the form of deaths and injuries of the people of the country (Frankonero, 2008). The majority of combatants are usually young male adults or adolescents. As they fight during the prime of their lives, the lives lost reduces the number of young people available to work and help their countries develop. "Between 1956 and 1965, 105,000 people are estimated to have been killed in Hutu/Tutsi conflict. According to Africa Council for Religions Leaders (2006), Small arms and light weapons are responsible for the majority of battle-related conflict deaths and an estimated 60-90 percent of all direct conflict victims are killed with firearms. Large numbers of men, women, older people and children die indirectly from the effects of armed conflict on the economy, ruined health and security infrastructures, disease and famine. In addition, many more people are made refugees or are internally displaced, injured or abused. Arms conflict fuels instability and poverty. Violence does not necessarily begin with a weapon, but it increases dramatically when weapons are present, particularly in already volatile environments rife with poverty, mistrust or injustice. Conflicts also impede the economic development of a country as it results in the displacement of a large number of people. Similar to direct costs, the productive age demographic is lost to the country in the short term and with them the future generations are also lost. Even though in some cases those displaced do return to their country of origin, a large proportion of the displaced settle as refugees in host countries. 
In central and eastern Africa according to Africa Council for Religions Leaders (2006), many lives have been lost through conflict and its related effects. In 1994, an interethnic conflict in Rwanda left more than 800,000 people murdered, mostly with small arms, including machetes. An estimated 300,000 civilians have also lost their lives the same way in Burundi. However, the foreign supply of arms to both governments and rebel groups continues to grow in illicit, ungoverned or poorly controlled transactions. The small arms that are already in the sub region move easily across borders between Cameroon, Chad and the Central African Republic.

According to Oxfam Research Reports (2017) data on conflict fatalities in Africa are scarce and inconsistent, however, most deaths recorded in conflict and security-challenged environments in the continent are caused by uncontrolled arms. For example, an estimated 1,689 to 3,713 were killed between 2012 and 2014 in Mali alone. Most of these deaths were civilians killed by rebels and other armed groups Oxfam Research Reports (2017). Beyond the numbers, killings involving illicit arms are horrific and psychologically devastating to victims and their relatives. For example, Seydou, 34, lost his parents to heavily armed bandits who shot them and looted their home in northern Mali. In Beni in DRC, around 600 Congolese have died since 2014, and 64 bodies with gunshot wounds were recovered by local officials after rebels attacked the village in August 2016. Similarly, in CAR, Halimatou, 42, a Muslim woman, was forced to watch as her husband was shot with a pistol and hacked to death by anti Balaka fighters according to Oxfam Research Reports (2017). Another example is that of Patricia, 43, whose son was killed by a stray bullet fired by a militia; a situation that has left her psychologically scarred and mentally unwell. Estimates of Libya's body count show that 2,825 and 1,523 people were killed in 2014 and 2015, respectively, and up to August in 2016, 902 deaths have been recorded. While the figures of deaths in recent years are dwarfed by the estimated 50,000 fatalities in 2011, the huge arsenals of uncontrolled arms in the possession of non-state armed groups, and increasing reports of clashes with progovernment forces, suggests that unarmed civilians will continue to be victims of uncontrolled arms. According to Oxfam Research Reports (2017) also revealed that, data on refugees and IDPs are fluid and varied, they point to massive displacements of people due to the increased deadliness of armed groups and conflicts. Available data shows that 466,000 and 434,174 Central Africans are refugees and IDPs respectively. Based on UNHCR's 2015 estimates, as a percentage of its population, CAR has one of the highest amounts of IDPs and refugees Oxfam Research Reports (2017). As of July 2016, the total figure of DRC refugees in neighbouring countries was estimated at 450,474, while the number of registered refugees in Congo was put at 387,963. From 31 May to 31 July 2016, the UNHCR recorded 201,642 DRC refugees in Uganda, 73,504 in Rwanda, 61,090 in Tanzania, 53,669 in Burundi, 14,908 in South Sudan, 12,269 in Congo Brazzaville, 4,836 in CAR, 997 in Ethiopia and 799 in Sudan.82 The International Organization for Migration (IOM) Displacement Tracking Matrix Round 5 Report of August 2016 set the total estimate of IDPs in Libya at 348, 372. This reflects a slight drop from the July 2015 estimate by the Internal Displacement Monitoring Centre (IDMC) that put IDPs in Libya at 434,000. Statistics from UNHCR show that more than 134,000 Malian refugees are in neighbouring Mauritania, Burkina Faso and Niger, and over 36,000 are internally displaced. The UNHCR also put the total figure of registered Somali refugees at 972,215 , as at July 2016, while 1.3 million are internally displaced.86 UNHCR estimates the number of South Sudanese refugees to be 1,291,323.87 Uganda and Sudan have received 110,000 and 100,000, of them respectively Oxfam Research Reports (2017).

The estimated 20 million small arms that are circulating throughout western Africa play a central role in fostering instability. According to Africa Council for Religions Leaders (2006), demand for small arms in West Africa is motivated by weak governance, insecurity and poverty. The supply comes mostly from external sources. They have been used in armed robberies, intra- and inter-communal feuds, local wars, armed insurrections, armed rebel activities and terrorism. They are used to facilitate drug trafficking, smuggling and other such crimes. Overall, small arms maintain a general state of fear. As a result of the armed conflict in the region, many people have been killed; many others displaced or made refugees and property destroyed. Every country in West Africa has experienced widespread violence in which small arms were a factor.

Small arms affect development in the most basic way because they are the tools of conflict. It impact negatively on the economic development of the Sub Saharan Africa as high levels of insecurity continue to deter economic development sustenance initiatives and cause increased military spending, which divert state resources from critical areas. During conflict, physical and human resources are destroyed; transit routes or fertile areas are blocked and diverted; and sometimes national industries are corrupted or taken over by armed groups. Foreign investors and aid agencies are discouraged from proceeding with essential projects and support. All of this undermines halts or prevents development. As insecurity becomes more prevalent, businesses shut down as owners flee, burglary and theft take place resulting in losses for businesses. Once order is restored, the business owners may have been displaced or even have lost their lives. Foreign investors become weary of investing in the country for fear of losing their investment. As a result of the conflict, economic development comes to a stop and at times is reversed.

In Darfur, for example, security deteriorated rapidly in 2005 as armed forces terrorized civilians. Many development organizations withdrew thousands of personnel who had been delivering critical basic services to 
displaced citizens. The cost of conflict on African development was approximately $\$ 300$ billion between 1990 and 2005, according to research by Oxfam International, IANSA and Safer world. The report shows that on average, a war, civil war or insurgency shrinks an African economy by 15 percent. The continent loses an average of around $\$ 18$ billion a year due to armed conflict.

Public health can be greatly affected by the proliferation and misuse of small arms. Violence leads to injury; injury requires care and when there is widespread injury, it is all too easy for health care systems in developing countries to become overwhelmed. Tending to victims of armed violence can also divert medical resources away from those who are ill or need other attention. The cost of medical care for these individuals can be overwhelming and, for some, may last a lifetime. Moreover, it is not uncommon for armed groups to target health workers, hospitals, ambulances and clinics. In many conflict zones, transportation routes used for the distribution of food and medicine are insecure due to the proliferation or threat of small arms, and sanitation and water purification systems break down, leading to outbreaks of diseases such as cholera.

Finally, the proliferation of small arms and light weapons, particularly guns, contributes to gender inequality and violence against women around the world. Men are the primary users and victims of guns, but women are continually victimized by them to a disproportionate degree. In conflict and post-conflict zones, women and girls suffer from a variety of harmful effects related to the threat and misuse of small arms. For example, sexual violence such as rape, sexual slavery and forced impregnation are the common tactics of war. Even in times of peace women remain subject to violence and intimidation, often in their homes. Women are much more likely to be shot with a legally held weapon by someone they know well than by an anonymous assailant

\section{Conclusion and Recommendations}

Preventing illicit arms transfers requires the adoption of policies, procedures, and practices aimed at controlling their import, export, transit, retransfer, and end use. The misuse of SALW and the illicit transfer of weapons to combatants, criminals, and terrorists will require a fresh strategic approach with more defined objectives and greater commonality across the multilateral system. While the illicit proliferation of SALW presents one of the gravest security threats in modern times, norms and frameworks, such as the Programme of Action and the International Tracing Instrument, have been implemented with measured success. While concerted efforts have been made to address the multifaceted problems related to SALW, patchwork solutions and inconsistent adherence to global standards still persist. To address the ill effects of SALW effectively, concerted global action is required, expanding the leadership role of multilateral institutions, not only as norm-setters, but as facilitators, matching needs with resources and enabling the establishment of regional arrangements.

Also, comprehensive implementation of the UN small arms instruments should remain a principal focus of further efforts to combat the proliferation and misuse of small arms effectively. Officials have to take steps to remedy any weaknesses in controls at their own national levels that facilitate and contribute to small arms diversions and the illicit small arms trade. States that have not yet done so need to review their national controls and their implementation in light of their commitments under the UN instruments on small arms. Where relevant, states should define a national strategy for ensuring their compliance with the UN instruments and the responsible management of small arms. The consensus-based proceedings under the UN program of action impose clear limits on what may be achieved at the global level in light of the current opposition by some states to the introduction of further standards to control the small arms trade. This does not mean that there is no scope for the strengthening of already existing standards. States should also make greater efforts at national and regional levels to address the problem of small arms proliferation and misuse. Otherwise, there remains the clear risk that the illicit small arms trade and its devastating impact will continue unabated.

In addition, government must rein- forces her political commitment to implementing the provisions of the Instrument of the UN to combat the illicit of Small Arms and Light Weapons. Establishing agencies to coordinate policy and research on the illicit small arms trade and identifying points of contact to liaise between these national agencies and UN is the most basic and the easiest to implement of the pillars. Adoption of a national arms control strategy (NACS) to guide the clean-up and prevention of SALWs in circulation is necessary. The proposed establishment of a National Commission on the Control of Small Arms and Light Weapons (NATCOM) should be fast-tracked to lead this effort, involving collaboration with Civil Society Organizations (CSOs), National Taskforce (NATFORCE) and other stakeholders.

Government must also, develop strategies that address the reasons why individuals, groups, and governments seek weapons in the first place. Such strategies must reflect an understanding of the complexities of violence in conflict zones, crime-ridden countries, and countries recovering from war and should involve government officials, local community leaders, and NGOs. These strategies must be linked to other aspects of violence-reduction and disarmament programs, such as security sector reform, and build them into existing programs, such as DDR programs, by providing populations with ways to achieve security and power other than through armed. 
The Governments through multilateral and bilateral cooperation should also ensure cross-border cooperative measures within the neighbouring countries. They must be effectively and properly managed and with other action that can stamp out cross-border crimes rather than, just empty gestures. The proliferation of light weapons occupies pride of place. Light weapons are widely used in African conflicts, in particular owing to their "advantages" they are cheap, easy to transport and conceal, simple to maintain and easy to handle. Therefore, Success in efforts to combat the proliferation of light weapons will largely depend on political will, as displayed in particular in cooperation between states. This cooperation, which is currently at an embryonic stage, should be organized on clearly spelt-out legal foundations with a well-defined strategy for action.

In addition, to ensure that weapons are used for lawful purposes, governments should establish domestic ownership licensing and authorization systems that take into consideration the applicant's history of violent behavior, mental health, age, and knowledge of the laws and the safe operation of weapons, among other criteria. More so, those states that have not criminalized the unauthorized export, use, and ownership of weapons should do so immediately and those governments that are not yet doing so should train their law enforcement personnel in the internationally accepted codes of conduct for firearms use and monitor their compliance with codes.

Internationally, the implementation and enforcement of national and international arms embargoes must be improved. Particularly important are UN arms embargoes, violations of which must be thoroughly investigated and punished by the international community. At the national level, those governments that lack authorization systems for the production and transfer of small arms and light weapons should establish them immediately, and countries with weak systems should take steps to strengthen them. Many governments still do not require authentication of end-user certificates, review proposed exports against a list of eligibility criteria, or monitor the end use of exported small arms in the sine qua non of an effective transfer control system. The armed forces and security forces have a variety of intelligence networks. Coordinating the work of these networks to combat the illegal circulation of small arms could substantially reduce the proliferation of such weapons. Only appropriate intelligence services can help in an effective way to identify the groups and individuals that are engaged in the manufacture, sale, storage, transfer, possession and illegal funding of this category of weapon. This will call for sophisticated intelligence equipment such as electronic communication facilities, scanners, digital fingerprinting machines, radios, computers and vehicles.

Road blocks should be seen as one of the efforts to combat the proliferation of small arms, constant road checks must be organized with the aim of apprehending the individuals being sought and preventing trafficking in arms and ammunition. For this purpose, road blocks should be set up on the main highways, secondary roads and even footpaths. The numbers of security personnel involved in these operations will depend on the number of roads to be covered and the volume of road traffic. Experience shows that road blocks constitute one of the most effective means of combating the proliferation of small arms at the national and regional levels.

A clear, comprehensive set of laws, regulations, and administrative procedures that covers all aspects of the manufacture, transport, storage, transfer, and disposal of small arms and light weapons is a prerequisite to an effective regional response to their illicit proliferation and misuse. Because governments cannot lock up gun runners if their activities are not criminal offenses, the PoA requires that member states outlaw the unauthorized manufacture, possession, stockpiling, and trade of small arms and light weapons. Yet, many countries still have not criminalized some or all of the activities identified in the PoA. Only about three-quarters of UN member states have laws and procedures that criminalize the illicit possession of small arms, and only two-thirds criminalize the illicit manufacture and trade of these weapons.

\section{Reference}

Ake, C. (1985) Political Economy of Nigeria, London: Longman Group.

Ake, C. (2001) Democracy and Development in Africa, Ibadan: Spectrum Books.

Anna K. \& Nicolas, F. (2005) Sourcing the Tools of War: Small Arms Transfers to Conflict Zones Chapter · June.

Anyanwu, U. (2005). Failed states in Africa: The Nigerian case since 1960. American Journal of International Politics and Development Studies, 1(1), 109-117.

Bahati, J. (2009)"Impact of Small Arms Proliferation on Africa". Afjn.org. Africa Faith \& Justice Network.

Berman, E. G. and Jonah, Leff. (2008). 'Light Weapons: Products, Producers, and Proliferation.' In Small Arms Survey. Small Arms Survey 2008: Risk and Resilience. Cambridge: Cambridge University Press, pp. 6-41.

ECOWAS Convention on Small Arms and Light Weapons, their Ammunition and Other Related Materials,2006.http://www.poaiss.org/RegionalOrganizations/ECOWAS/ECOWAS\%20Convention\%2020 06.pdf

Francis, L. K (2009) Small arms and light weapons transfer in West Africa: a stock-taking; the-complexdynamics-of-small-arms-in-west-Africa- Printed at United Nations, Geneva-January $2009-4,480$ UNIDIR/2009/1 ISSN 1020-7287.

Frankonero, N. (2008) Effects of Proliferation of Small Arms in Sub-Sahara Africa; USAWC Strategy Research 
Project

Hocker, W. (1995). Interpersonal conflict. Dubuque, Iowa: W.C. Brown.

Jeffrey. B and Michael, K. (1998) Light Weapons and Civil Conflict: Controlling the Tools of Violence, Massachusetts; forthcoming from Rowman \& Littlefield, spring.

Jeffrey, B. Michael T. Klare and Laura W. Reed, eds(1998) Lethal Commerce : The Global Trade in Small Arms and Light Weapons, Jeffrey Cambridge, MA: American Academy of Arts and Sciences, p. 9

International Action Network on Small Arms (IANSA),(2007) “Gun Violence: The Global Crisis," London .

Kofi, A. (2010), Millennium report to UN General Assembly (UNGA), New York, USA.

McDonald, G. (2005).'Strengthening Controls: Small Arms Measures.' In Small Arms Survey. Small Arms Survey 2002: Counting the Human Cost. Oxford: Oxford University Press, pp. 234-77.

Marx, K. and Engels, F.(1977) Manifesto of the Communist Party, Moscow: Progress Publishers.

Osimen, G.U. and Akintunde, B.A. (2015), "Small Arms and Light Weapons (SALW) Proliferation and Problems of National Security in Nigeria", International Affairs and Global Strategy, Volume 29, 2015

Oxfam (November 2016). From Pledge to Commitment. https://www.oxfam.org/sites/ www.oxfam.org/files/bncar-pledge-to-commitment-151116-en_0.pdf,

Oxfam Research Reports (March 2017). The Human Cost of Uncontrolled Arms in Africa Cross-national research on seven African countries

Steven, H. (1996) "Post-Conflict Reconstruction," Environmental Department, Work in Progress, The World Bank, Social Policy and Resettlement Division, 1996, p. 1.

See Africa council for Religions Leaders (2006) "Small Arms and Light Weapons: Africa A Resource Guide for Religions for Peace.

See Report of the Panel of Governmental Experts on Small Arms," Report \#A/52/298, from the Secretary General to the UN General Assembly, August 27, 1997.

See "Small Arms and Light Weapons Survey (1997). The Epidemic Spread of Conflicts," Conversion Survey, Bonn: Bonn International Center for Conversion.

See Small Arms Survey (2013), "Weapons and the World: Learning from Africa”, Cambridge Reporting, No. 33. August 2013.

See Small Arms Survey (2016). Definitions of Small Arms and Light Weapons. http://www.smallarmssurvey.org/weapons-and-markets/definitions.html

Swadesh, R.(1995) Small Arms and Intra-State Conflicts, New York: United Nations, 1995, p. 4.

UN (2008). Programme of Action to Prevent, Combat and Eradicate the Illicit Trade in Small Arms and Light Weapons in All Its Aspects (UN Document A/CONF.192/15). http://www.poaiss.org/PoA/poahtml.aspx

UNGA (United Nations General Assembly) (2005). Resolution 49/159, adopted 23 December. A/RES/49/159 of 24 February 2005.

UN Institute for Disarmament Research (UNIDR) (2006) "Developing a Mechanism to Prevent Illicit Brokering in Small Arms and Light Weapons," November 28, p. 16 